\title{
Transactions
}

\section{Synthesis, structural characterization, antimicrobial and cytotoxic effects of aziridine, 2-aminoethylaziridine and azirine complexes of copper(II) and palladium(II) $\uparrow+$}

\author{
E. Budzisz, ${ }^{* a}$ R. Bobka, ${ }^{b}$ A. Hauss, ${ }^{b}$ J. N. Roedel, ${ }^{b}$ S. Wirth, ${ }^{b}$ I.-P. Lorenz, ${ }^{* b}$ B. Rozalska, ${ }^{c}$ M. Więckowska- \\ Szakiel, ${ }^{c}$ U. Krajewska ${ }^{d}$ and M. Rozalski ${ }^{d}$
}

Received 4th November 2011, Accepted 8th March 2012

DOI: $10.1039 / \mathrm{c} 2 \mathrm{dt} 12107 \mathrm{~g}$

The synthesis, spectroscopic and X-ray structural characterization of copper(II) and palladium(II) complexes with aziridine ligands as 2-dimethylaziridine $\mathrm{HNCH}_{2} \mathrm{CMe}_{2}$ (a), the bidentate $\mathrm{N}$-(2aminoethyl)aziridines $\mathrm{C}_{2} \mathrm{H}_{4} \mathrm{NC}_{2} \mathrm{H}_{4} \mathrm{NH}_{2}$ (b) or $\mathrm{CH}_{2} \mathrm{CMe}_{2} \mathrm{NCH}_{2} \mathrm{CMe}_{2} \mathrm{NH}_{2}$ (c) as well as the unsaturated azirine $\mathrm{NCH}_{2} \mathrm{CPh}$ (d) are reported. Cleavage of the cyclometallated $\mathrm{Pd}$ (II) dimer $\left[\mu-\mathrm{Cl}\left(\mathrm{C}_{6} \mathrm{H}_{4} \mathrm{CHMeNMe}_{2}-\right.\right.$ $C, N) \mathrm{Pd}]_{2}$ with ligand a yielded compound $\left[\mathrm{Cl}\left(\mathrm{NHCH}_{2} \mathrm{CMe}_{2}\right)\left(\mathrm{C}_{6} \mathrm{H}_{4} \mathrm{CHMe}_{2} \mathrm{NMe}_{2}-C, N\right) \mathrm{Pd}\right]$ (1a). The reaction of the aziridine complex trans- $\left[\mathrm{Cl}_{2} \mathrm{Pd}\left(\mathrm{HNC}_{2} \mathrm{H}_{4}\right)_{2}\right]$ with an excess of aziridine in the presence of AgOTf gave the ionic chelate complex trans- $\left[\left(\mathrm{C}_{2} \mathrm{H}_{4} \mathrm{NC}_{2} \mathrm{H}_{4} \mathrm{NH}_{2}-N, N^{\prime}\right)_{2} \mathrm{Pd}\right](\mathrm{OTf})_{2}(\mathbf{2 b})$ which contains the new ligand $\mathbf{b}$ formed by an unexpected insertion and ring opening reaction of two aziridines ("aziridine dimerization"). $\mathrm{CuCl}_{2}$ reacted in pure $\mathrm{HNC}_{2} \mathrm{H}_{4}$ or $\mathrm{HNCH}_{2} \mathrm{CMe}_{2}$ (b) again by "dimerization" to give the tris-chelated ionic complex $\left[\mathrm{Cu}\left(\mathrm{C}_{2} \mathrm{H}_{4} \mathrm{NC}_{2} \mathrm{H}_{4} \mathrm{NH}_{2}-N, N^{\prime}\right)_{3}\right] \mathrm{Cl}_{2}$ (3b) or the bis-chelated complex $[\mathrm{CuCl}$ $\left.\left(\mathrm{C}_{2} \mathrm{H}_{2} \mathrm{Me}_{2} \mathrm{NC}_{2} \mathrm{H}_{2} \mathrm{Me}_{2} \mathrm{NH}_{2}-\mathrm{N}, \mathrm{N}^{\prime}\right)_{2}\right] \mathrm{Cl}(4 \mathrm{c})$. By addition of $2 \mathrm{H}$-3-phenylazirine (d) to $\mathrm{PdCl}_{2}$, trans- $\left[\mathrm{Cl}_{2} \mathrm{Pd}\right.$ $\left(\mathrm{NCH}_{2} \mathrm{CPh}\right)_{2}$ ] (5d) was formed. All new compounds were characterized by NMR, IR and mass spectra and also by X-ray structure analyses (except $\mathbf{3 b}$ ). Additionally the cytotoxic effects of these complexes were examined on HL-60 and NALM-6 human leukemia cells and melanoma WM-115 cells. The antimicrobial activity was also determined. The growth of Gram-positive bacterial strains (S. aureus, S. epidermidis, E. faecalis) was inhibited by almost all tested complexes at the concentrations of 37.5-300.0 $\mu \mathrm{g} \mathrm{mL}^{-1}$. However, MIC values of complexes obtained for Gram-negative E. coli and $P$. aeruginosa, as well as for $C$. albicans yeast, mostly exceeded $300 \mu \mathrm{g} \mathrm{mL}^{-1}$. The highest antibacterial activity was achieved by complexes $\mathbf{1 a}$ and $\mathbf{2} \mathbf{b}$. Complex $\mathbf{2} \mathbf{b}$ also inhibited the growth of Gram-negative bacteria.

\section{Introduction}

The high interest that the chemistry of aziridines attracts is generated by the manifold applications of these smallest saturated azaheterocycles. $^{1-3}$ Aziridines are not only used as reactive synthons in organic synthesis, in the synthesis of peptides and natural products, ${ }^{4,5}$ but also as monomeric units in

\footnotetext{
${ }^{a}$ Department of Cosmetic Raw Materials Chemistry, Faculty of Pharmacy, Medical University of Lodz, Muszynski Str. 1, 90-151 Lodz, Poland.E-mail: elzbieta.budzisz@umed.lodz.pl

${ }^{b}$ Department of Chemistry, Ludwig-Maximilians-University, Butenandtstr. 5-13 (D), D-81377 Munich, Germany. E-mail: ipl@cup.uni-muenchen.de

${ }^{c}$ Department of Immunology and Infectious Biology, University of Lodz, Banacha 12/16, 90-237 Lodz, Poland

${ }^{d}$ Department of Pharmaceutical Biochemistry, Medical University of Lodz, Muszynski Str. 1, 90-151 Lodz, Poland

$\dagger$ Dedicated to Prof. Dr Wolfgang Beck on the occasion of his 80th birthday.

$\$$ CCDC 849020-849023. For crystallographic data in CIF or other electronic format see DOI: $10.1039 / \mathrm{c} 2 \mathrm{dt} 12107 \mathrm{~g}$
}

polymerization reactions ${ }^{6}$ or as natural and synthetic pharmaceuticals. ${ }^{7-9}$ Though the parent aziridine $\mathrm{C}_{2} \mathrm{H}_{4} \mathrm{NH}$ is classified as mutagenic, ${ }^{10,11}$ there are some aziridine-containing natural compounds known to be useful as chemotherapeutics to combat cancer targeting biochemical processes. Good examples are the family of mitomycins and acinomycins. ${ }^{12-14}$ Their physiological effect relies on their poor stability towards ring opening followed by alkylation and cross-linking to form DNA interstrands. This leads to the inhibition of DNA replication and to cell death. There are also some man-made aziridine derivatives with similar antitumor capabilities based on the exact same cytotoxic effect, e.g. some aziridinylbenzoquinones, ${ }^{15,16} \mathrm{TEM},{ }^{17}$ or thioTEPA. ${ }^{18}$ This ring-opening reaction of aziridines by nucleophilic attack is very similar to that of isoelectronic oxiranes and thiiranes. With regard to coordination chemistry, however, the reactivity of nucleophilic aziridines towards electrophilic transition metal centers differs strongly from those of oxiranes and thiiranes with a only few exceptions. ${ }^{19-21}$ While the latter act as oxidizing agents towards organometallic complexes resulting in the formation of oxo- or thiocomplexes via ethene 
elimination, ${ }^{22-26}$ aziridines usually remain intact and prefer metal coordination via the nitrogen atom. Therefore, only one example of two-fold breakage of $\mathrm{C}-\mathrm{N}$ bonds, elimination of ethene and formation of an imido complex is known in the literature. ${ }^{26}$ However, many aziridine complexes of a variety of transition metals with up to four aziridine ligands are currently known, most of which have been published by us. ${ }^{27-41}$ Ring opening reactions especially with functionalized metal carbonyls have also been reported, e.g. with hydrido carbonyl complexes to form $\beta$-aminoacyl complexes via $\mathrm{M}-\mathrm{C}$ addition ${ }^{42-46}$ or with halogenido carbonyl complexes to form five-membered aminooxycarbene complexes. ${ }^{47,48}$

Transition metal-mediated ring opening reactions of aziridine ligands yielding aminoethylaziridine- $N, N^{\prime}$ complexes by "aziridine dimerization" was first observed by Beck et al. ${ }^{49}$ and Fritz et $a l .{ }^{50}$ The first examples of such an aziridine dimer template have been structurally characterized by X-ray determination in the case of a cationic $\mathrm{Co}(\mathrm{III})$ complex bearing two dimerized 2methylaziridine ligands. ${ }^{51}$ We later reported further examples of analogous complexes with dimerized aziridine ligands. ${ }^{52,53}$ Furthermore, most recently a novel route to $N$-(2-aminoethyl)aziridines was developed based on the one reported by Beck et al. ${ }^{49}$ utilizing a $\mathrm{Cu}$ (II)-mediated template dimerization of aziridine ligands. ${ }^{53}$

In this paper we report on the synthesis and characterization of new palladium(II) and copper(II) complexes with dimerized aziridine ligands as well as of palladium(II) complexes with one $\mathrm{N}$-bound aziridine ligand and two azirine ligands, respectively. Hitherto, only a few azirine complexes of transition metals are known. ${ }^{54,55}$ Usually they undergo ring-opening or rearrangement reactions in the presence of transition metals. ${ }^{56,57}$ Because of the successful employment of aziridine-containing mitomycin derivatives in cancer therapy, some of their transition metal complexes have been synthesized, which did not show significant differences in biological activity compared to the uncoordinated compounds. ${ }^{58}$ The cis-bisaziridine Pt(II) complex ${ }^{59,60}$ analogous to cisplatin showed no better activity, but had higher selectivity. Therefore all the synthesized complexes here have been investigated for their biological activity.

\section{Results and discussion}

\section{Synthesis of the complexes $1 a, 2 b, 3 b, 4 c$ and $5 d$}

The cleavage reaction of the chlorido-bridged dimer bis $[\mu-\mathrm{Cl}(S)$ 2 -\{1-(dimethylamino)ethyl $\}$ phenyl- $C, N$-palladium(II) $]^{61}$ with an excess of 2,2-dimethylaziridine (a) in $\mathrm{CH}_{2} \mathrm{Cl}_{2}$ affords the square planar palladium(II) complex $\mathrm{Cl}\left(\mathrm{C}_{6} \mathrm{H}_{4} \mathrm{CHCH}_{3} \mathrm{NMe}_{2}-\mathrm{C}, N\right)$ -
$\left(\mathrm{NHCH}_{2} \mathrm{CMe}_{2}\right) \mathrm{Pd}$ (1a) (Scheme 1). Light yellow 1a is obtained with $50 \%$ yield, and is air-stable, soluble in polar solvents $\left(\mathrm{CH}_{2} \mathrm{Cl}_{2}\right)$, but insoluble in non-polar solvents (n-pentane). The spectroscopic characterization showed the evidence of $S, S$ and $R$, $R$ enantiomers due to $N$ chirality at the aziridine nitrogen.

The starting material for the synthesis of complex $\mathbf{2 b}$ is the bisaziridine complex trans- $\left[\mathrm{Cl}_{2} \mathrm{Pd}\left(\mathrm{NHC}_{2} \mathrm{H}_{4}\right)_{2}\right] .{ }^{62}$ When it is treated with at least 3 equivalents of aziridine $\mathrm{HNC}_{2} \mathrm{H}_{4}$ and 2 equivalents of $\mathrm{AgOTf}$ in $\mathrm{CH}_{2} \mathrm{Cl}_{2}$ at r.t., the cationic square planar palladium(II) complex $\left[\left(\mathrm{C}_{2} \mathrm{H}_{4} \mathrm{NC}_{2} \mathrm{H}_{4} \mathrm{NH}_{2}-\mathrm{N}, N^{\prime}\right)_{2} \mathrm{Pd}\right]-$ $(\mathrm{OTf})_{2}$ (2b) with $2 \mathrm{OTf}^{-}$as counteranions is formed (Scheme 2). As already published by us in the case of copper(II) complexes, the bidentate $\beta$-aminoethylaziridine ligand $\mathbf{b}$ is formed by a metal-induced dimerization reaction. Hitherto, this unusual reaction was only observed for $\mathrm{HNC}_{2} \mathrm{H}_{4}{ }^{52}$ and its monoand dimethyl derivatives $\mathrm{HNCH}_{2} \mathrm{CHMe}^{51}$ and $\mathrm{HNCH}_{2} \mathrm{CMe}_{2}{ }^{63}$ as is also shown in the following syntheses of complexes $\mathbf{3 b}$ and 4c. Thus, it seems that this "aziridine dimerization" is limited by steric reasons. Yellow $\mathbf{2 b}$ is soluble in polar solvents, even methanol, but insoluble in non-polar solvents such as n-pentane, and under argon it can be stored indefinitely.

The first aziridine complexes of copper(II) have been published by Edwards et al. in $1961^{64,65}$ and by Beck et al. in $1973,{ }^{49}$ but without any structural characterization. Beck et al. also observed the first "aziridine dimerization" induced by metal coordination. ${ }^{49}$ This has been recently proven by our own results with some aziridine complexes of copper(II). In most cases, however, several derivatives of aziridines kept intact and coordinated as ligands in $1: 2,1: 3$ and $1: 4$ molar ratios to $\mathrm{Cu}$ (II) centers. ${ }^{53,66,67}$ To increase this stoichiometry and to obtain hexaaminecopper(II) analogous complexes, we decided to use a large excess of aziridine and to avoid using any solvent. Therefore, anhydrous $\mathrm{CuCl}_{2}$ was added directly to the liquid aziridines $\mathrm{C}_{2} \mathrm{H}_{4} \mathrm{NH}$ or $\mathrm{CH}_{2} \mathrm{CMe}_{2} \mathrm{NH}$ (a), respectively. As shown in Scheme 3, two different ionic complexes with different stoichiometry and coordination geometry were obtained depending on the substituents. In the case of aziridine, $\mathrm{C}_{2} \mathrm{H}_{4} \mathrm{NH}$, the tris-chelated octahedral complex $\left[\left(\mathrm{C}_{2} \mathrm{H}_{4} \mathrm{NC}_{2} \mathrm{H}_{4} \mathrm{NH}_{2}-N, N^{\prime}\right)_{3} \mathrm{Cu}_{2}\right] \mathrm{Cl}_{2}$ (3b) resulted and in the case of the 2,2-dimethylderivative the bischelated trigonal bipyramidal complex $\left[\left(\mathrm{CH}_{2} \mathrm{CMe}_{2} \mathrm{NCH}_{2} \mathrm{C}-\right.\right.$ $\left.\left.\mathrm{Me}_{2} \mathrm{NH}_{2}-N, N^{\prime}\right) \mathrm{ClCu}\right] \mathrm{Cl}(\mathbf{4 c})$. Both complexes, however, again contain the corresponding "dimerized" aziridines as ligands b and $\mathbf{c}$. Our attempts to obtain single crystals of $\mathbf{3 b}$ by recrystallisation were not successful, because it was destroyed by any longer attack of polar solvents. Using methanol for instance, caused the formation of the bis-chelated complex trans$\left[\left(\mathrm{C}_{2} \mathrm{H}_{4} \mathrm{NC}_{2} \mathrm{H}_{4} \mathrm{NH}_{2}-N, N^{\prime}\right)_{2}(\mathrm{HOMe})_{2} \mathrm{Cu}\right] \mathrm{Cl}_{2}$ with two $\mathrm{MeOH}$ ligands in axial positions as proven by $\mathrm{X}$-ray structural

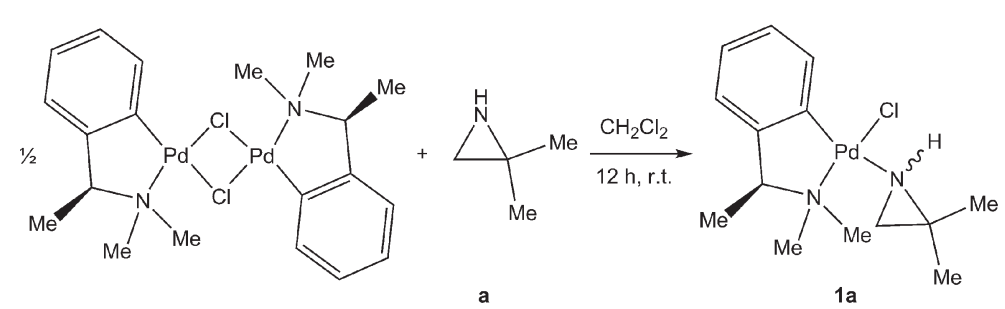

Scheme 1 Synthesis of the neutral palladium(II) complex 1a with ligand 2,2-dimethylaziridine (a). 


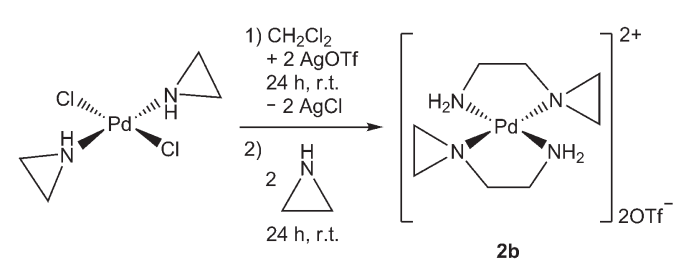

Scheme 2 Synthesis of the ionic palladium(II) complex $\mathbf{2 b}$ with ligand $\mathrm{N}$-(2-aminoethyl)aziridine (b) formed by metal-induced "aziridine dimerization" of $\mathrm{C}_{2} \mathrm{H}_{4} \mathrm{NH}$.

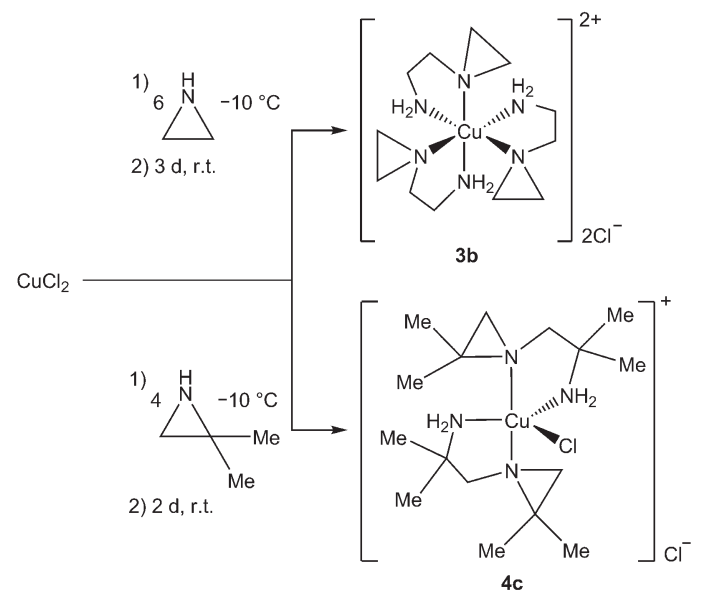

Scheme 3 Synthesis of the ionic copper(II) complexes $\mathbf{3 b}$ and $\mathbf{4 c}$ with ligands $N$-(2-aminoethyl)aziridine (b) and $N$-(2-amino-2-methylpropyl)2,2-dimethylaziridine (c) both again formed by metal-induced "aziridine dimerization".

analysis. $^{53} \mathbf{4 c}$ is soluble in slightly polar solvents such as acetone or dichloromethane, insoluble in non-polar solvents such as n-pentane. Both complexes are air-stable.

Azirine ligands were mentioned in palladium(II) complexes by several groups in 1978. ${ }^{54-56}$ One of them presented with trans[(2H-3-tolylazirine $\left.)_{2} \mathrm{Cl}_{2} \mathrm{Pd}\right]$ the only example structurally characterized by diffraction studies. ${ }^{55}$ The syntheses of azirine complexes turned out to be difficult because of subsequent rearrangement reactions in the presence of metal complexes and too long reaction times. If the reaction can be stopped, however, it is possible to isolate some palladium(II) complexes of the type trans $-\left[(2 \mathrm{H} \text {-3-arylazirine })_{2} \mathrm{Cl}_{2} \mathrm{Pd}\right]$ (aryl $=\mathrm{C}_{6} \mathrm{H}_{5}$ (d), $\mathrm{C}_{6} \mathrm{H}_{4} \mathrm{Cl}$, $\mathrm{C}_{6} \mathrm{H}_{4} \mathrm{Br}$ ) by the reaction of $\mathrm{PdCl}_{2}$ and $2 \mathrm{H}$-3-arylazirine in acetonitrile. ${ }^{66}$ Here we only present the synthesis and structural characterization of the phenyl derivative 5d (Scheme 4), once formed and isolated, stable enough for the implemented analytical and biological studies in low concentration. $\mathbf{5 d}$ is obtained as air-stable orange yellow powder in $65 \%$ yield and is soluble in $\mathrm{CH}_{2} \mathrm{Cl}_{2}$ and $\mathrm{CHCl}_{3}$, but insoluble in n-hexane.

\section{Spectroscopic characterization}

All the complexes have been characterized by their ${ }^{1} \mathrm{H}$ and ${ }^{13} \mathrm{C}$ NMR, IR and mass spectra with the exception of the copper(II) complexes $\mathbf{3 b}$ and $\mathbf{4 c}$, where characterization by NMR

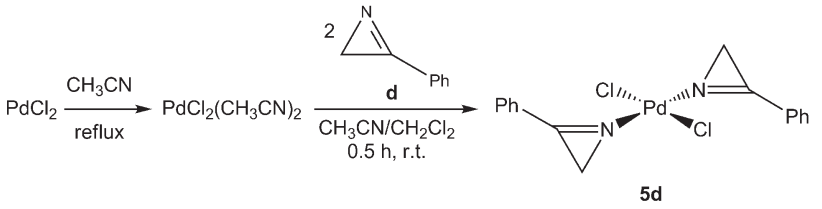

Scheme 4 Synthesis of the neutral palladium(II) complex 5d with ligand $2 \mathrm{H}$-3-arylazirin (d).

spectroscopy was not possible because of their paramagnetic properties.

The IR spectrum of 1a shows $v(\mathrm{NH})$ absorptions slightly shifted by coordination to lower frequencies at about $3100 \mathrm{~cm}^{-1}$. Somewhat lower are found the $v(\mathrm{CH})$ bands $\left(2971-2833 \mathrm{~cm}^{-1}\right)$. Two striking absorptions between 1600 and $1500 \mathrm{~cm}^{-1}$ are assigned to $v(\mathrm{C}=\mathrm{C})$ of the $N, N$-dimethylbenzylamine moiety. In the IR spectrum of $\mathbf{2 b}$, analogous absorptions for $v(\mathrm{NH})$ and $v(\mathrm{CH})$ are found in the same region as for 1a. Besides this, a weak band for $\delta\left(\mathrm{NH}_{2}\right)$ at $1608 \mathrm{~cm}^{-1}$ is observed. Additionally, the typical strong bands of the triflate anion appear in the region $1280-1030 \mathrm{~cm}^{-1}$ for the $v\left(\mathrm{CF}_{3}\right)$ and $v\left(\mathrm{SO}_{3}\right)$ vibrations. The IR spectra of the ionic copper complexes $\mathbf{3 b}$ and $\mathbf{4} \mathbf{c}$ are very similar to each other and similar to that of $\mathbf{2} \mathbf{b}$. The $v(\mathrm{NH})$ and $v(\mathrm{CH})$ absorptions are found at $3240-3100$ and $3000-2870 \mathrm{~cm}^{-1}$ respectively, as well as the $\delta\left(\mathrm{NH}_{2}\right)$ at $1604(3 \mathrm{~b})$ and $1602 \mathrm{~cm}^{-1}$ (4c). The azirine complex 5d shows only the $v(\mathrm{CN})$ absorption at $1771 \mathrm{~cm}^{-1}$ as significant, besides the expected ones for $v(\mathrm{CH})$ and $v(\mathrm{C}=\mathrm{C})$.

The ${ }^{1} \mathrm{H}$ and ${ }^{13} \mathrm{C}$ NMR spectra of 1 a point to the evidence of the intact $N$-bound aziridine ligand a. The $\mathrm{CH}_{3}$ and $\mathrm{CH}_{2}$ proton signals show the typical low field shifts caused by metal coordination. The $\mathrm{CH}_{3}$ signals are found at 1.53 and $1.52 \mathrm{ppm}$ instead of $0.96 \mathrm{ppm}$ for free a, the $\mathrm{CH}_{2}$ signals lie at 2.50 and $2.09 \mathrm{ppm}$ (1.26 ppm free a). Analogously, the signals of the $C_{\mathrm{q}}$ and $\mathrm{CH}_{2}$ carbon atoms appear about +8 and $+4 \mathrm{ppm}$ further downfield than those of free a $\left(C_{\mathrm{q}} 31.0 \mathrm{ppm}, \mathrm{CH}_{2} 33.3 \mathrm{ppm}\right)$. Concerning the $\mathrm{CH}_{3}$ carbon signals, complexation causes only slight shifts of about 0.3 and $1.0 \mathrm{ppm}$. It should be mentioned that both the ${ }^{1} \mathrm{H}$ and ${ }^{13} \mathrm{C}$ NMR spectra of 1 a show a pair for each signal (which overlap in some cases) suggesting the presence of diastereomers in 1a, which contains an asymmetric carbon and nitrogen atom. Starting off enantiomerically pure $(S, S)$ $\left[\mathrm{C}_{6} \mathrm{H}_{4} \mathrm{CHCH}_{3} \mathrm{NMe}_{2} \mathrm{PdCl}\right]_{2}$, the coordination of the incoming bridge-splitting aziridine $\mathbf{a}$ is completely regioselective. This is caused by the known electronic directing effect of $\mathrm{Pd}-\mathrm{Cl}$ bonds $^{68-70}$ to yield pure $\left(S_{\mathrm{C}}, S_{\mathrm{N}}\right)$ and $\left(S_{\mathrm{C}}, R_{\mathrm{N}}\right)$-1a with the az- $N$ taking up the position trans to the $\mathrm{NMe}_{2}$ group. As the corresponding proton signals of both diastereomers are finely separated, especially at the chiral amine ligand, the integration of the signals of $\mathrm{C}_{6} \mathrm{H}_{4} \mathrm{CHMeNMe} 2$ delivers a ratio of about $40: 60\left(S_{\mathrm{C}}\right.$, $\left.S_{\mathrm{N}}\right):\left(S_{\mathrm{C}}, R_{\mathrm{N}}\right)$ enantiomers. The new dimerized ligand $\mathbf{b}$ can be well observed in its ${ }^{1} \mathrm{H}$ and ${ }^{13} \mathrm{C}$ NMR spectra by the signals of the ethane bridge. They are shifted downfield to 2.34 and $2.90 \mathrm{ppm}$ or 42.87 and $62.56 \mathrm{ppm}$, respectively compared to the $\mathrm{C}_{2} \mathrm{H}_{4}$ signals of the aziridine ring ( 1.40 and $1.87 \mathrm{ppm}$ or 28.30 and $33.98 \mathrm{ppm}$, respectively). The protons of the $\mathrm{NH}_{2}$ group could not be detected clearly as they are shifted to low field and overlayed by the signals of the $\mathrm{C}_{2} \mathrm{H}_{4}$ bridge. 
The azirine ligand in $\mathbf{5 d}$ shows a low field shift in the ${ }^{1} \mathrm{H}$ and ${ }^{13} \mathrm{C}$ NMR spectra compared to free ligand $\mathbf{d}$ only for the methylene protons. Because both ligands $\mathbf{d}$ are chemically equivalent, only one signal for $\mathrm{CH}_{2}$ at $20.9 \mathrm{ppm}$ (d: $19.2 \mathrm{ppm}$ ) is observed. While the azirine $C_{\mathrm{q}}$ signal of $\mathbf{5 d}$ is slightly shifted to lower field at $166.8 \mathrm{ppm}(\mathbf{d}: 165.3 \mathrm{ppm})$, the $C_{\mathrm{q}}$ signal of the phenyl ring is found at higher field (121.6 ppm, d: $125.1 \mathrm{ppm}$ ). In both spectra of $\mathbf{5 d}$ the three types of protons and $\mathrm{C}$ atoms appear separately and can be easily identified (see Experimental part).

The mass spectrum $\left(\mathrm{FAB}^{+}\right)$of $\mathbf{1 a}$ features the parent peak with $m / z=362$ for $\left[\mathrm{M}^{+}\right]$at relatively low intensity $(22 \%)$ with the typical isotope pattern. In the further fragmentation, first the loss of $\mathrm{Cl}(\mathrm{m} / \mathrm{z}=325,100 \%)$ and then of aziridine a with $\mathrm{m} / \mathrm{z}=254$ $(13 \%)$ occurs. In the mass spectrum of $\mathbf{2 b}$ not only the parent signal for the cation with $m / z=277(80 \%)\left[\mathrm{M}^{+}\right]$and one at $\mathrm{m} / \mathrm{z}$ $=191(48 \%)\left[\mathrm{M}^{2+}-\mathbf{b}\right]$ after elimination of one ligand $\mathbf{b}$ was detected, but also a signal at $m / z=427(93 \%)\left[\mathrm{M}^{2+}+\right.$ OTf] with one triflate still attached to the complex.

The mass spectra of both copper(II) complexes $\mathbf{3 b}$ and $\mathbf{4 c}$ show the cation parent peaks at $\mathrm{m} / \mathrm{z}=321(4 \%)$ and $\mathrm{m} / \mathrm{z}=383$ $(67 \%)$. For $3 \mathbf{b}$ a signal at higher mass at $m / z=356$ for $\left[\mathrm{M}^{2+}+\right.$ $\mathrm{Cl}]$ is observed as well as the corresponding signals after fragmentation of $n \mathbf{b}$ ligands $(n=1,2)$. The mass spectrum of $\mathbf{4 c}$ shows the expected fragmentation pattern with signals at $\mathrm{m} / \mathrm{z}=$ $348(30 \%)\left[\mathrm{M}^{+}-\mathrm{Cl}\right], 240(100 \%)\left[\mathrm{M}^{+}-\mathbf{c}\right]$ and $205(74 \%)\left[\mathrm{M}^{+}\right.$ $-\mathrm{Cl}-\mathbf{c}]$. In the case of the azirine complex 5d the parent signal $\left[\mathrm{M}^{+}\right]$was not detected, but there was a signal at $m / z=377$ $(100 \%)\left[\mathrm{M}^{+}-\mathrm{Cl}\right]$.

In the UV/Vis spectra of both $\mathrm{Cu}(\mathrm{II})$ complexes $\mathbf{3 b}$ and $\mathbf{4 c}$ a broad, unstructured absorption is observed with a maximum at $721 \mathrm{~nm}\left(\mathbf{3 b}, \varepsilon=279 \mathrm{~L} \mathrm{~mol}^{-1} \mathrm{~cm}^{-1}\right)$ and $796 \mathrm{~nm}(\mathbf{4 c}, \varepsilon=380 \mathrm{~L}$ $\mathrm{mol}^{-1} \mathrm{~cm}^{-1}$ ). In spite of the low symmetry caused by the chelating ligands, no shoulder or splitting is observable. The measured values, however, correspond to those of similar $\mathrm{Cu}$ (II) complexes with coordination numbers of five and six..$^{71,72}$

\section{Molecular structures of $1 \mathrm{a}, 2 \mathrm{~b}, 4 \mathrm{c}$ and $5 \mathrm{~d}$}

Single crystals of the complexes were grown from their solutions in $\mathrm{CH}_{2} \mathrm{Cl}_{2}(\mathbf{1} \mathbf{a}, \mathbf{4} \mathbf{c}$ and $\mathbf{5 d})$ or $\mathrm{CH}_{3} \mathrm{OH}(\mathbf{2} \mathbf{b})$ by isothermic diffusion of n-pentane. Their solid-state structures have been solved by X-ray diffraction and are shown in Fig. 1-4 together with selected bond lengths and bond angles. The crystallographic data are summarized in Table 1 .

As expected for the $4 \mathrm{~d}^{8}$ configuration, 1a exhibits a slightly distorted square planar geometry at palladium(II) with a small tilt from planarity of only $4.43^{\circ}$ between the C5-Pd1-N2 and Cl1Pd1-N1 planes (Fig. 1). The cis angles at the Pd1 center range between $81^{\circ}$ and $96^{\circ}$. The five-membered dimethyl-1-phenylethaneamine-2- $C, N$ chelate ring adopts the envelope conformation with palladium and the three carbon atoms $\mathrm{C} 5, \mathrm{C} 10$ and C11 being essentially coplanar (dihedral angle Pd1-C5-C10$\mathrm{C} 11=1.57^{\circ}$ ). The nitrogen atom of $\mathrm{NMe}_{2}$ lies $0.726 \AA$ off this plane. The aziridine ring is almost an equilateral triangle as its $\mathrm{C}-\mathrm{C}$ and $\mathrm{C}-\mathrm{N}$ bond lengths (1.476(5) $\AA$ and $1.483(4) / 1.495(4)$ $\AA$, respectively) and angles (59.4(2)-60.6(2) ${ }^{\circ}$ ) differ only slightly from those for free aziridine in the solid state. ${ }^{73}$ It is noteworthy that the Pd1-N2 bond (2.099(3) $\AA$ ) is somewhat longer than that of Pd1-N1 (2.047(3) A). All other Pd1-X

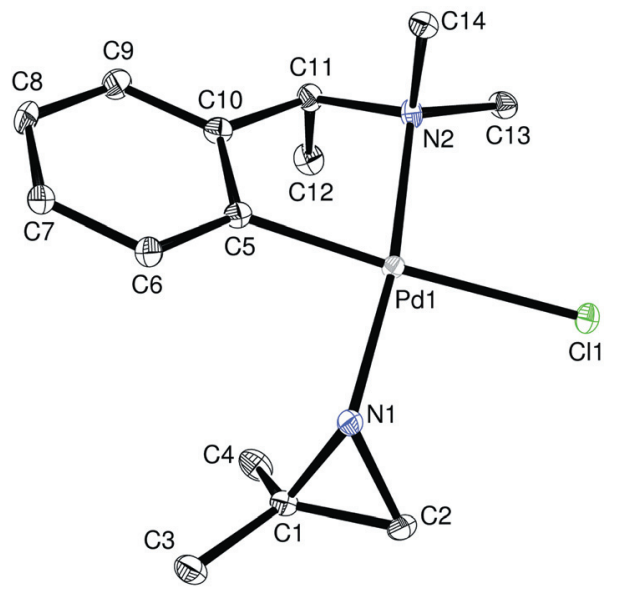

Fig. 1 Molecular structure of complex 1a with selected bond lengths $(\AA)$ and angles $\left({ }^{\circ}\right) . S_{\mathrm{c}}, R_{\mathrm{N}}$ isomer, only one of the four independent molecules in the asymmetric unit is shown. Thermal ellipsoids are drawn at the $30 \%$ probability level, $\mathrm{H}$ atoms are omitted for clarity. Pd1-N1 2.047(3), Pd1-N2 2.099(3), Pd1-C5 1.983(3), Pd1-Cl1 2.4326(8), N1C1 1.495(4), N1-C2 1.483(4), C1-C2 1.476(5), C1-C3 1.521(5), C1C4 1.506(4); C5-Pd1-N1 90.94(12), C5-Pd1-N2 81.41(12), N1-Pd1Cl1 91.75(8), N2-Pd1-Cl1 96.06(7), N1-Pd1-N2 171.67(10), C5-Pd1Cl1 176.06(10), C2-C1-N1 59.9(2), C1-C2-N1 60.7(2), C2-N1-C1 $59.4(2)$.

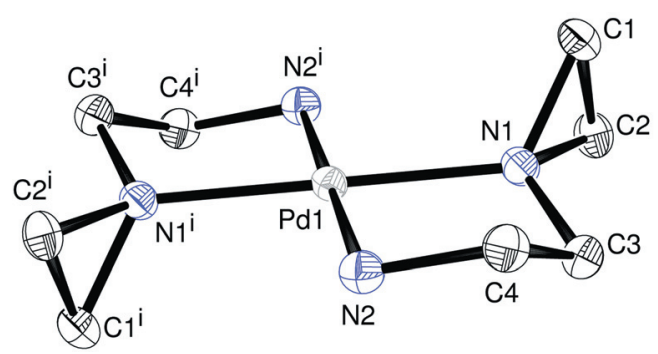

Fig. 2 Molecular structure of complex $\mathbf{2 b}$ with selected bond lengths $(\AA)$ and angles $\left({ }^{\circ}\right)$. H atoms and anions (triflate) are omitted for clarity. Thermal ellipsoids are drawn at the $30 \%$ probability level. Pd1-N1 2.0339(16), Pd1-N2 2.0458(18), N1-C1 1.487(3), N1-C2 1.478(3), C1-C2 1.477(3), C3-C4 1.499(3); N1-Pd1-N2 82.71(7), N1-Pd1-N2 ${ }^{\mathrm{i}}$ 97.29(7), N1-Pd1-N1 ${ }^{\mathrm{i}}$ 180.0, N2-Pd1-N2 ${ }^{\mathrm{i}} 180.0, \mathrm{~N} 1-\mathrm{C} 1-\mathrm{C} 259.82$ (13), N1-C2-C1 60.44(13), C1-N1-C2 59.74(14).

distances (X = C5: 1.983(3) $\AA, X=C l: 2.4326(8) \AA)$ lie in the expected range.

The cation of compound $\mathbf{2 b}$ has an inversion center at the $\mathrm{Pd}(\mathrm{II})$ center surrounded by four nitrogen atoms in a square planar geometry (Fig. 2). The trans N-Pd1-N angles are exactly $180^{\circ}$, while the cis N-Pd1-N angles vary between $82.7^{\circ}$ and $97.3^{\circ}$ because of the five-membered chelating ligand in a twist configuration. Both of the intact aziridine rings are orientated almost vertical $\left(81.54^{\circ}\right)$ to the molecular square plane. The Pd1$\mathrm{N} 2$ bond length $(2.0458(18) \AA$ ) is only slightly longer than that of Pd1-N1 (2.0339(16) $\AA$ ). The same is observed for the $\mathrm{C}-\mathrm{C}$ bonds of the ethane bridge (C3-C4 1.499(3) $\AA$ ) and of the aziridine ring $(1.477(3) \AA)$. The $\mathrm{C}-\mathrm{N}$ bonds $(1.476(3) / 1.485(3) \AA)$ and all angles of the aziridine ring $\left(59.74(14)-60.44(13)^{\circ}\right)$ show similar values to those in $\mathbf{1 a}$. 


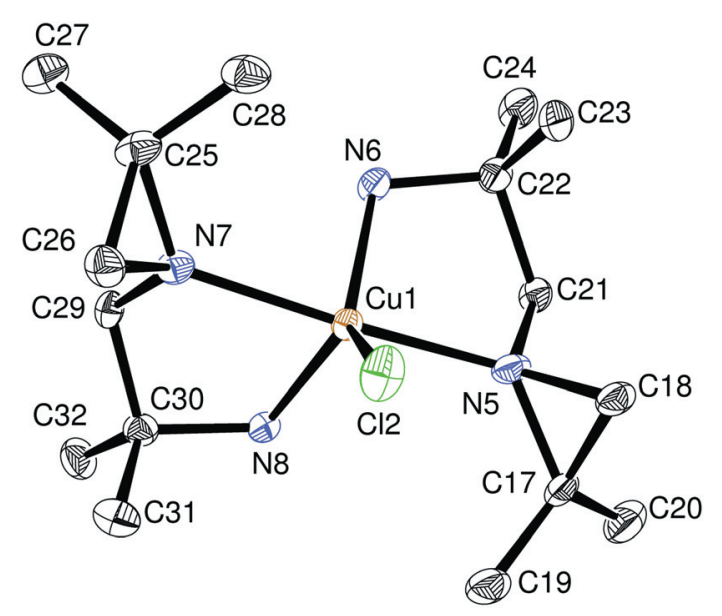

Fig. 3 Molecular structure of complex $\mathbf{4 c}$ with selected bond lengths $(\AA)$ and angles $\left({ }^{\circ}\right)$. Thermal ellipsoids are drawn at the $30 \%$ probability level, $\mathrm{H}$ atoms, anions (chlorine) and a second molecular unit are omitted for clarity. Cu1-Cl2 2.309(2), Cu1-N5 2.066(7), Cu1-N6 2.105 (5), Cu1-N7 2.074(6), Cu1-N8 2.145(6), N5-C17 1.517(8), N5-C18 1.495(8), C17-C18 1.513(10), N5-C21 1.484(8), N6-C22 1.467(9), C21-C22 1.540(8); N5-Cu1-N7 172.8(2), N6-Cu1-N8 96.5(2), N6Cu1-Cl2 136.80(19), N8-Cu1-Cl2 126.67(15), N5-Cu1-N6 83.0(2), N5-Cu1-N8 94.5(2), N5-Cu1-Cl2 94.7(2), N7-Cu1-N6 90.6(2), N7Cu1-N8 82.8(2), N7-Cu1-Cl2 92.30(15), N5-C17-C18 59.1(4), N5C18-C17 60.5(4), C17-N5-C18 60.3(4).

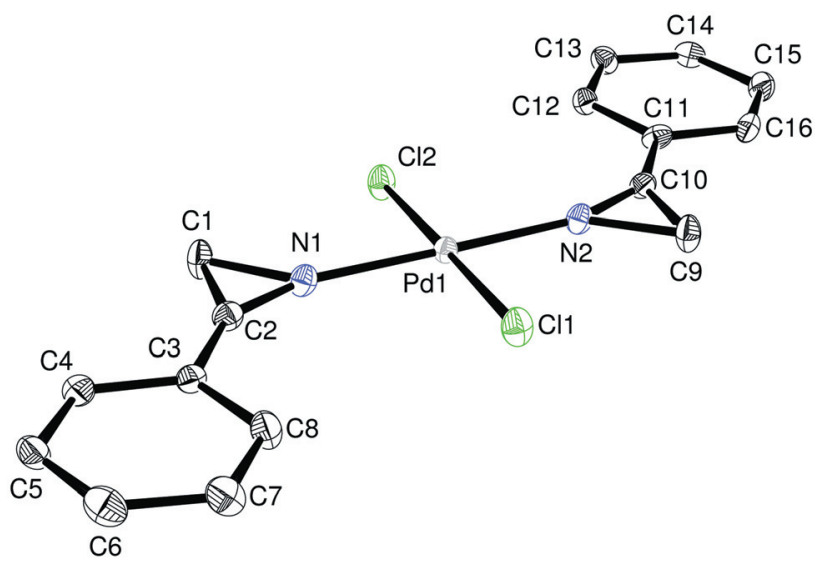

Fig. 4 Molecular structure of complex 5d with selected bond lengths $(\AA)$ and angles $\left({ }^{\circ}\right)$. Thermal ellipsoids are drawn at the $30 \%$ probability level, H atoms are omitted for clarity. Pd1-N1 1.994(4), Pd1-N2 1.973 (4), Pd1-Cl1 2.3009(15), Pd1-Cl2 2.2957(15), N1-C1 1.504(7), N1-C2 1.245(6), C1-C2 1.463(7); N1-Pd1-N2 179.3(3), N1-Pd1-Cl1 92.09 (14), N1-Pd1-Cl2 87.89(15), Cl1-Pd1-Cl2 179.38(5), C1-N1-Pd1 137.5(3), C1-N1-C2 63.5(3), N1-C1-C2 49.6(3), N1-C2-C1 66.9(3).

In the unit cell of complex $\mathbf{4 c}$ are two independent molecular units with only a few slight differences in their structural parameters. Therefore, only one is discussed and shown in Fig. 3. The $\mathrm{Cu}$ (II) center shows a distorted trigonal bipyramidal geometry surrounded by four nitrogen atoms and one chlorido ligand. This and both $\mathrm{NH}_{2}$ groups lie within the equatorial plane, while both aziridine $\mathrm{N}$ atoms occupy the trans-axial positions. The equatorial angles differ greatly because of the steric demand of the chlorido ligand (N6-Cu1-Cl2 136.80(19) ${ }^{\circ}$, N8-Cu1-Cl2 $126.67(15)^{\circ}$ and $\left.\mathrm{N} 6-\mathrm{Cu} 1-\mathrm{N} 896.5(2)^{\circ}\right)$. The trans-axial angle N5-Cu1-N7 $\left(172.8(2)^{\circ}\right)$ is also affected. The angles between equatorial and axial ligands show values larger than $90^{\circ}$ (90.6-94. $7^{\circ}$ ) with the only exception of those two (N5-Cu1-N6 $83.0(2)^{\circ}$, N7-Cu1-N8 $\left.82.8(2)^{\circ}\right)$ caused by both five-membered chelate systems in twist conformation. All structural parameters of both aziridine rings range within normal values and correspond to those in $\mathbf{1 a}$ and $\mathbf{2 b}$.

Analogous trigonal bipyramidal $\mathrm{Cu}(\mathrm{II})$ complexes are rarely found in the literature. Normally, analogous geometries can be formed by multidentate ligands, e.g. $\left[\left(\mathrm{Cu}(\text { tren }) \mathrm{NH}_{3}\right) \mathrm{ClO}_{4}\right]_{2}{ }^{74}$ or by special polyhedral structures, e.g. in the tetrameric adamantane-analogous $\mu_{4}$-oxo-complex $\left[\left(\mu_{4}-\mathrm{O}\right)\left(\mu_{4}-\mathrm{Cl}\right)\left(\mathrm{C}_{2} \mathrm{H}_{4} \mathrm{NHCu}\right)_{4}\right]{ }^{75}$

The square planar azirine complex of palladium(II) 5d (Fig. 4) is slightly distorted because of the two different ligands, two chlorido ligands and two azirine-N atoms each in trans positions

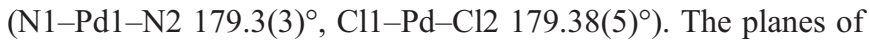
the azirine rings form different small angles to the equatorial $\mathrm{PdN}_{2} \mathrm{Cl}_{2}$ plane $\left(\Delta_{1}=2.56\right.$ and $\left.3.78^{\circ}\right)$ as well as to the phenyl plane $\left(\Delta_{2}=4.48\right.$ and $\left.5.63^{\circ}\right)$. Therefore, one can say that the whole molecule is nearly planar. Both $\mathrm{Pd}-\mathrm{Cl1} / \mathrm{Cl} 2$ and $\mathrm{Pd}-\mathrm{N} 1 /$ $\mathrm{N} 2$ bond lengths are nearly equal, the latter ones of course are shorter because of their $\mathrm{sp}^{2}$-hybridized $\mathrm{N}$-atoms than those in the aziridine complexes mentioned above. This is also observed in the structural parameters of the unsaturated azirine ring $(\mathrm{N} 1-\mathrm{C} 1$ 1.504(7), N1-C2 1.245(6) and C1-C2 1.463(7) $\AA$; C1-N1-C2 63.5(3), N1-C1-C2 49.6(3) and $\mathrm{N} 1-\mathrm{C} 2-\mathrm{C} 1$ 66.9(3) $\left.{ }^{\circ}\right)$ which differ significantly from those of the saturated aziridine rings.

\section{Biological studies}

The cytotoxicity of the complexes $\mathbf{1 a}, \mathbf{2 b}, \mathbf{3 b}, \mathbf{4 c}$ and $\mathbf{5 d}$ was assayed against human HL-60 and NALM-6 leukemia cells and melanoma WM-115 cells. During these tests no signs of decomposition were noticed. Cisplatin and carboplatin were used as reference compounds. Cells were exposed to a broad range of drug concentrations $\left(10^{-7}\right.$ to $\left.10^{-3} \mathrm{M}\right)$ for $48 \mathrm{~h}$ and cell viability was analyzed by MTT assay. $\mathrm{IC}_{50}$ values are presented in Table 2. The complexes $\mathbf{2 b}, \mathbf{3 b}$ and $\mathbf{5 d}$ exhibited the highest cytotoxic activity for HL-60 and NALM-6 cell lines, with IC $_{50}$ values in the range of 1.5-8.2 $\mu \mathrm{M}$. Interestingly, compound $\mathbf{3 b}$ was even more effective then reference drug cisplatin in the case of human skin melanoma WM-115 cells.

It was found that the growth of Gram-positive bacterial strains ( $S$. aureus, $S$. epidermidis and $E$. faecalis) was inhibited by almost all tested complexes at the concentrations of 37.5-300.0 $\mu \mathrm{g} \mathrm{mL}^{-1}$ (Table 3). On the other hand, MIC values of complexes obtained for Gram-negative E. coli and P. aerugi$n o s a$, as well as for C. albicans yeast, exceeded $300 \mu \mathrm{g} \mathrm{mL}^{-1}$. The exception was activity of $\mathbf{2} \mathbf{b}$ against $E$. coli and $P$. aeruginosa (at $75.0 \mu \mathrm{g} \mathrm{mL}^{-1}$ ) and $\mathbf{1 a}$ with the MIC for $E$. coli equal to $150.0 \mu \mathrm{g} \mathrm{mL}^{-1}$. In general, the highest activity was achieved by 2b. MICs of this complex were relatively low: $37.5 \mu \mathrm{g} \mathrm{mL}^{-1}$ for S. aureus and $18.75 \mu \mathrm{g} \mathrm{mL} \mathrm{m}^{-1}$ for $S$. epidermidis. The second complex with noticeable antimicrobial activity was 1a. It inhibited growth of Gram-positive cocci ( $S$. aureus, S. epidermidis and $E$. faecalis) at a concentration range of 75.0-150.0 $\mu \mathrm{g} \mathrm{mL}^{-1}$. 
Table 1 Crystallographic data for complexes $1 \mathrm{a}, \mathbf{2 b}, \mathbf{4 c}$ and $\mathbf{5 d}$

\begin{tabular}{|c|c|c|c|c|}
\hline Compound & 1a & $2 \mathbf{b}$ & $4 c$ & 5d \\
\hline FW & 361.22 & 576.83 & 418.94 & 411.62 \\
\hline Wavelength $/ \AA$ & 0.71073 & 0.71073 & 0.71073 & 0.71073 \\
\hline Crystal system & Monoclinic & Monoclinic & Orthorhombic & Orthorhombic \\
\hline Space group & $P 2_{1}$ & $P 2_{1} / c$ & Pna $_{1}$ & $\mathrm{Pca}_{1}$ \\
\hline a/Å & $10.7546(5)$ & 11.6261(3) & 24.9994(5) & $21.4333(5)$ \\
\hline$\alpha /^{\circ}$ & 90 & 90 & 90 & 90 \\
\hline$\beta /^{\circ}$ & $92.912(3)$ & $111.658(2)$ & 90 & 90 \\
\hline$\gamma /{ }^{\circ}$ & 90 & 90 & 90 & 90 \\
\hline$V / \AA^{3}$ & $3135.6(2)$ & $1048.36(4)$ & $4258.44(12)$ & $1530.58(6)$ \\
\hline$Z$ & 8 & 2 & 8 & 4 \\
\hline$\rho_{\mathrm{c}} / \mathrm{g} \mathrm{cm}^{-3}$ & 1.53036 & 1.82736 & 1.3069 & 1.78631 \\
\hline$\mu / \mathrm{mm}^{-1}$ & 1.340 & 1.170 & 1.281 & 1.554 \\
\hline & $-34 \leq k \leq 23$ & $-12 \leq k \leq 12$ & $-11 \leq k \leq 11$ & $-7 \leq k \leq 7$ \\
\hline & $-14 \leq l \leq 14$ & $-12 \leq l \leq 12$ & $-23 \leq l \leq 23$ & $-16 \leq l \leq 16$ \\
\hline Refls. collected & 18229 & 4640 & 7966 & 3291 \\
\hline Independent refls. & 10459 & 2400 & 4295 & 3291 \\
\hline$R_{\text {int }}$ & 0.0295 & 0.0142 & 0.0275 & 0.041 \\
\hline Completeness to $\theta$ & $99.4 \%$ & $99.5 \%$ & $99.4 \%$ & $99.7 \%$ \\
\hline Data/restraints/parameters & $10459 / 1 / 649$ & $2400 / 0 / 169$ & $4295 / 1 / 416$ & $3291 / 1 / 191$ \\
\hline$S$ on $F^{2}$ & 1.001 & 1.104 & 1.021 & 1.049 \\
\hline \multirow[t]{2}{*}{ Final $R$ indices $[I>2 \sigma(I)]$} & $R_{1}=0.0221, \mathrm{w} R_{2}=$ & $R_{1}=0.0228, \mathrm{w} R_{2}=$ & $R_{1}=0.0465, \mathrm{w} R_{2}=$ & $R_{1}=0.0322, \mathrm{w} R_{2}=$ \\
\hline & 0.0494 & 0.0523 & 0.1204 & 0.0730 \\
\hline$R$ indices (all data) & $R_{1}=0.0247, \mathrm{w} R_{2}=$ & $R_{1}=0.0278, \mathrm{w} R_{2}=$ & $R_{1}=0.0692, \mathrm{w} R_{2}=$ & $R_{1}=0.0473, \mathrm{w} R_{2}=$ \\
\hline & 0.0504 & 0.0546 & 0.1352 & 0.0808 \\
\hline Absolute structure parameter & $0.021(14)$ & - & $0.29(6)^{a}$ & $0.47(7)^{a}$ \\
\hline $\begin{array}{l}\text { Largest difference peak/hole } \\
{\left[\mathrm{e} \AA^{-3}\right]}\end{array}$ & $0.483 /-0.550$ & $0.605 /-0.552$ & $1.208 /-0.366$ & $2.186 /-0.618$ \\
\hline
\end{tabular}

${ }^{a}$ Structures $\mathbf{4 c}$ and $\mathbf{5 d}$ refined as twins (twinned by inversion) yielding BASF 0.2926 (4c) and 0.4697 (5d). The determination of the absolute structures is not possible.

Table $2 \mathrm{IC}_{50}$ values (in $\mu \mathrm{M}$ ) for complexes $\mathbf{1 a}, \mathbf{2 b}, \mathbf{3 b}, \mathbf{4 c}$ and $\mathbf{5 d}$

\begin{tabular}{llll}
\hline Compounds & HL-60 & NALM-6 $\mathrm{IC}_{50}{ }^{a}$ & WM 115 \\
\hline $\mathbf{1 a}$ & $56.4 \pm 2.3$ & $48.7 \pm 1.0$ & $62.4 \pm 3.4$ \\
$\mathbf{2 b}$ & $8.2 \pm 0.3$ & $7.2 \pm 0.5$ & $47.6 \pm 1.0$ \\
$\mathbf{3 b}$ & $1.53 \pm 0.30$ & $0.58 \pm 0.10$ & $5.9 \pm 0.9$ \\
$\mathbf{4 c}$ & $50.3 \pm 2.8$ & $48.1 \pm 3.0$ & $51.4 \pm 3.9$ \\
$\mathbf{5 d}$ & $4.6 \pm 0.7$ & $5.8 \pm 1.1$ & $84.6 \pm 2.8$ \\
Cisplatin & $0.8 \pm 0.1$ & $0.7 \pm 0.3$ & $18.2 \pm 4.3$ \\
Carboplatin & $4.3 \pm 1.3$ & $0.7 \pm 0.2$ & $422.2 \pm 50.2$
\end{tabular}

${ }^{a} \mathrm{IC}_{50}$ - concentration of a tested compound required to reduce the fraction of surviving cells to $50 \%$ of that observed in the control, nontreated cells. Data represents the mean value of at least three experiments, each performed at five repeats \pm S.D.

\section{Conclusion}

In the present paper the synthesis, characterization and crystal structures of three square planar palladium(II) complexes (1a, 2b and 5d) containing the ligands 2-dimethylaziridine- $N$ (a), $N$-(2aminoethyl)aziridine- $N, N^{\prime}$ (b) and 2H-3-phenylazirine (d) as well as of two copper(II) complexes (octahedral $\mathbf{3 b}$ and trigonal bipyramidal $\mathbf{4 c}$ ), where ligands $\mathbf{b}$ and $\mathbf{c}$ are dimers of the parent aziridine $\mathrm{C}_{2} \mathrm{H}_{4} \mathrm{NH}$ and its 2-dimethyl derivative a, are reported.
Table 3 Antimicrobial activity of complexes. MIC values $\left(\mu \mathrm{g} \mathrm{mL}{ }^{-1}\right)$ were determined by broth microdilution assay, according to CLSI recommendations

\begin{tabular}{|c|c|c|c|c|c|}
\hline \multirow[b]{2}{*}{ Microorganism } & \multicolumn{5}{|c|}{$\mathrm{MIC}\left(\mu \mathrm{g} \mathrm{mL}^{-1}\right)$} \\
\hline & $1 \mathbf{a}$ & $2 b$ & $\mathbf{3 b}$ & $4 c$ & $5 d$ \\
\hline $\begin{array}{l}\text { S. aureus (ATCC } \\
\text { 29213) }\end{array}$ & 150.0 & 37.5 & 300.0 & $>300.0$ & 300.0 \\
\hline $\begin{array}{l}\text { S. epidermidis (ATCC } \\
12228 \text { ) }\end{array}$ & 75.0 & 18.75 & 300.0 & $>300.0$ & 300.0 \\
\hline $\begin{array}{l}\text { E. faecalis (ATCC } \\
\text { 29212) }\end{array}$ & 150.0 & 150.0 & 300.0 & $>300.0$ & 300.0 \\
\hline E. coli (NCTC 8196) & 150.0 & 75.0 & $>300.0$ & $>300.0$ & $>300.0$ \\
\hline $\begin{array}{l}\text { P. aeruginosa (NCTC } \\
6749)\end{array}$ & $>300.0$ & 75.0 & $>300.0$ & $>300.0$ & $>300.0$ \\
\hline $\begin{array}{l}\text { C. albicans (ATTC } \\
\text { 10231) }\end{array}$ & $>300.0$ & $>300.0$ & $>300.0$ & 300.0 & $>300.0$ \\
\hline
\end{tabular}

This unexpected dimerization occurs via insertion and ring opening reaction of two aziridines by metal-induced activation. Though aziridines are considered to be highly mutagenic, all the complexes have been examined for cytotoxic and antimicrobial properties. To the best of our knowledge this is the first time such directed investigations have been carried out. All the novel 
aziridine-containing complexes are promising compounds with high antitumor activity and two of them, $\mathbf{1 a}$ and $\mathbf{2} \mathbf{b}$, also show remarkable antibacterial activity. Many natural or synthetic compounds show activity against Gram-positive bacteria but not against Gram-negative species or fungi, which have evolved significant permeability barriers. Thus, it is worth emphasizing that in our experiments the Gram-negative bacteria were susceptible to damage by one of complexes used (2b). It suggests that this compound may easily penetrate biological membranes probably without any help of active transport mechanisms and may be promising as a future therapeutic agent and alternative to antibiotics. However, on the basis of this study it is difficult to predict its mechanisms of action.

\section{Experimental}

\section{Materials and methods}

All experiments were performed under a dry argon atmosphere using Schlenk line techniques. The separation of phases in heterogeneous reaction mixtures was carried out by centrifugation with subsequent pipetting or by filtration. Reagents were commercially available and used without further purification. The starting complexes $\left[\mu-\mathrm{Cl}\left(\mathrm{C}_{6} \mathrm{H}_{4} \mathrm{CHMeNMe}_{2}-C, N\right) \mathrm{Pd}\right]_{2}{ }^{61}$ and trans $-\left[\mathrm{C}_{2} \mathrm{H}_{4} \mathrm{NHPdCl}\right]_{2}{ }^{62}$ were prepared according to literature methods. The solvents were purified by standard procedures; $\mathrm{CH}_{2} \mathrm{Cl}_{2}$ was distilled from calcium hydride, n-pentane from lithium aluminium hydride and methanol from $\mathrm{MgH}_{2}$. All dried solvents were stored under a dry $\mathrm{Ar}$ atmosphere with $3 \AA$ molecular sieves. NMR spectra were recorded using a Jeol Eclipse 270 or a Jeol Eclipse 400 spectrometer operating at $270 \mathrm{MHz}$ $\left({ }^{1} \mathrm{H}\right)$ and $68 \mathrm{MHz}\left({ }^{13} \mathrm{C}\right)$ or $400 \mathrm{MHz}\left({ }^{1} \mathrm{H}\right)$ and $100 \mathrm{MHz}\left({ }^{13} \mathrm{C}\right)$, respectively. The ${ }^{1} \mathrm{H}$ and ${ }^{13} \mathrm{C}$ chemical shifts were determined relative to TMS as an internal standard. IR spectra were recorded using a Perkin Elmer Spectrum One FT-IR-Spectrometer in the range of $4000-400 \mathrm{~cm}^{-1}$. UV/visible (UV/Vis) data were recorded with a Varian Cary $50 \mathrm{UV} / \mathrm{Vis}$ spectrophotometer at room temperature. Mass spectra were obtained with a JEOL MStation MS-700, NBA matrix (FAB). Multi-isotope containing fragments refer to the isotope with the highest abundance. Elemental analyses were performed by the Microanalytical Laboratory of the Department of Chemistry, LMU Munich, using a Heraeus Elementar Vario El. Single crystal X-ray data were collected with a Nonius Kappa CCD diffractometer $(\mathbf{2 b}, \mathbf{4 c}, \mathbf{5 d})$ equipped with a rotating anode generator or an Oxford Diffraction XCalibur diffractometer (1a), both using graphite-monochromated Mo- $\mathrm{K}_{\alpha}$ radiation $(\lambda=0.71073 \AA)$. Structures were solved by direct methods using the SHELXS software and refined on $F^{2}$ by full-matrix least-squares with SHELXL-97. ${ }^{76}$ CCDC numbers in Table 1 contain the supplementary crystallographic data for this paper.t

\section{Synthesis of the palladium(II) and copper(II) complexes 1a, 2b,} $3 b, 4 c$ and $5 d$

Chlorido-(2,2-dimethylaziridine)-[2-\{1-(dimethylamino)ethyl\}phenyl- $\boldsymbol{C}, \boldsymbol{N}]$-palladium(II) (1a). 6 equivalents of 2,2-dimethylaziridine (a) $(66.1 \mu \mathrm{L}, 0.732 \mathrm{mmol})$ were added to a solution of bis[ $\mu$-chlorido-[(S)-2-\{1-(dimethylamino)ethyl $\}$ phenyl- $C, N$ -

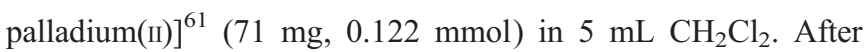
$12 \mathrm{~h}$ of stirring at r.t., the solvent was removed in vacuo and the residue was purified by stirring in dry $\mathrm{n}$-heptane $(10 \mathrm{~mL})$ for $12 \mathrm{~h}$ at r.t. Yield $44 \mathrm{mg}(0.122 \mathrm{mmol}, 50 \%)$, light grey powder, m.p. $157^{\circ} \mathrm{C}$. Elemental analysis: Found: N, 7.72; C, 46.58; H, 6.45. Calc. for $\mathrm{C}_{14} \mathrm{H}_{23} \mathrm{ClN}_{2} \mathrm{Pd}\left(361.22 \mathrm{~g} \mathrm{~mol}^{-1}\right)$ : N, 7.76; $\mathrm{C}$, 46.55 ; H, 6.42\%. IR: $v_{\max } / \mathrm{cm}^{-1}(\mathrm{KBr}) 3139 \mathrm{vs}(\mathrm{NH}), 3105 \mathrm{~s}$, 2971s (CH), 2912m (CH), 2856m (CH), 2833w (CH), 2788w, $1579 \mathrm{w}, 1458 \mathrm{~s}, 1446 \mathrm{~s}, 1384 \mathrm{~s}, 1370 \mathrm{~m}, 1340 \mathrm{~s}, 1290 \mathrm{w}, 1251 \mathrm{w}$, $1175 \mathrm{w}, 1175 \mathrm{w}, 1146 \mathrm{~m}, 1114 \mathrm{~s}, 1062 \mathrm{w}, 1030 \mathrm{w}, 1011 \mathrm{~m}, 981 \mathrm{w}$, 939s, 921s, 812s, 786w, 756vs, 729s, 661w, 557w. ${ }^{1} \mathrm{H}$ NMR (270.17 MHz, $\mathrm{CD}_{2} \mathrm{Cl}_{2}$ ): $\delta=7.00-6.82(\mathrm{~m}, 4 \mathrm{H}, \mathrm{Ar}-\mathrm{CH}), 3.62$ and 3.53 (two signals for $S, S$ and $S, R$ enantiomer, quartet, ${ }^{3} \mathrm{~J}_{\mathrm{H}-\mathrm{H}}$ $=6.5 \mathrm{~Hz}, 0.4 \mathrm{H}$ and $0.6 \mathrm{H}, \mathrm{C} H \mathrm{Me}), 2.75$ and $2.59(\mathrm{~s}, 1.5 \mathrm{H}$ each, $\left.\mathrm{NCH}_{3}\right), 2.63$ and $2.56\left(\mathrm{~s}, 1.5 \mathrm{H}\right.$ each, $\left.\mathrm{NCH}_{3}\right), 2.50\left(\mathrm{~d}, \mathrm{br},{ }^{3} J_{\mathrm{H}-\mathrm{NH}}\right.$ $\left.=5.9 \mathrm{~Hz}, 1 \mathrm{H}, \mathrm{az}-\mathrm{CH}_{2}\right), 2.09\left(\mathrm{~d}, \mathrm{br},{ }^{3} J_{\mathrm{H}-\mathrm{NH}}=7.4 \mathrm{~Hz},{ }^{2} J_{\mathrm{H}-\mathrm{H}}=\right.$ $\left.2.1 \mathrm{~Hz}, 1 \mathrm{H}, \mathrm{az}-\mathrm{CH}_{2}\right), 1.53$ (s, $\left.3 \mathrm{H}, \mathrm{az}-\mathrm{CH}_{3}\right), 1.52$ (s, $3 \mathrm{H}, \mathrm{az}-$ $\left.\mathrm{CH}_{3}\right), 1.46$ and $1.42\left(\mathrm{~s},{ }^{3} \mathrm{~J}_{\mathrm{H}-\mathrm{H}}=6.5 \mathrm{~Hz}, 1.5 \mathrm{H}\right.$ each, $\left.\mathrm{CHCH}_{3}\right)$. ${ }^{13} \mathrm{C}$ NMR, DEPT: $\left(67.93 \mathrm{MHz}, \mathrm{CD}_{2} \mathrm{Cl}_{2}\right): \delta=154.0$ and 153.6 $\left(\mathrm{Ar}-C_{\mathrm{q}}\right), 147.5$ and $147.2\left(\mathrm{Ar}-C_{\mathrm{q}}-\mathrm{Pd}\right), 131.6(\mathrm{Ar}-\mathrm{CH}), 124.5$ and 124.8 (Ar-CH), 124.2 and 124.1 (Ar-CH), 122.1 and $122.0(\mathrm{Ar}-$ $\mathrm{CH}), 76.2$ and $75.6\left(>\mathrm{CHCH}_{3}\right), 52.2$ and $51.9\left(>\mathrm{NCH}_{3}\right), 48.0$ and $47.2\left(>\mathrm{NCH}_{3}\right), 38.9$ and $38.7\left(\mathrm{az}-\mathrm{C}_{\mathrm{q}}\right), 37.5$ and 37.4 (az$\left.\mathrm{CH}_{2}\right), 25.8$ and $25.5\left(\mathrm{az}-\mathrm{CH}_{3}\right), 25.4$ and $25.0\left(\mathrm{az}-\mathrm{CH}_{3}\right), 20.9$ and $19.2\left(>\mathrm{CHCH}_{3}\right) . \mathrm{MS}\left(\mathrm{FAB}^{+}\right): m / z(\%)=362(22)\left[\mathrm{M}^{+}\right], 325$ (100) $\left[\mathrm{M}^{+}-\mathrm{Cl}\right], 254(13)\left[\mathrm{M}^{+}-\mathrm{Cl}-\mathbf{a}\right], 211(11)[\mathrm{Pd}+\mathrm{Cl}+\mathbf{a}]$.

[Bis( $N$-(2-aminoethyl)aziridine- $\left.N, N^{\prime}\right)$ palladium(II)]bis(trifluormethansulfonate) (2b). To a suspension of $100 \mathrm{mg}$ $(0.380 \mathrm{mmol})$ trans-[bis(aziridine)dichloridopalladium(II)] $\left(\left(\mathrm{C}_{2} \mathrm{H}_{4} \mathrm{~N}\right)_{2} \mathrm{Cl}_{2} \mathrm{Pd}\right)^{62}$ in $20 \mathrm{~mL} \mathrm{CH} \mathrm{Cl}_{2}, 205 \mathrm{mg}(0.797 \mathrm{mmol})$ AgOTf was added. After stirring at r.t. for $24 \mathrm{~h}$ the precipitate of $\mathrm{AgCl}$ was separated by centrifugation. The resulting solution was combined with $61.4 \mu \mathrm{L}(1.14 \mathrm{mmol})$ aziridine $\mathrm{C}_{2} \mathrm{H}_{4} \mathrm{NH}$, whereby it become clouded. After stirring again at r.t. for $24 \mathrm{~h}$ the solvent was removed in vacuo. The crude residue was purified by stirring in n-hexane and separation by pipetting two times; afterwards it was dried in vacuo. Yield $108 \mathrm{mg}$ (0.187 mmol, 50\%), light yellow solid, m.p. $176{ }^{\circ} \mathrm{C}$ (dec.). Elemental analysis: Found: C, 21.09; H, 3.88; N, 9.15. Calc. for $\mathrm{C}_{10} \mathrm{H}_{20} \mathrm{~F}_{6} \mathrm{~N}_{4} \mathrm{O}_{6} \mathrm{PdS}_{2}\left(576.83 \mathrm{~g} \mathrm{~mol}^{-1}\right): \mathrm{C}, 20.82 ; \mathrm{H}, 3.49 ; \mathrm{N}$, 9.71\%. IR: $v_{\max } / \mathrm{cm}^{-1}(\mathrm{KBr}) 3252 \mathrm{~m}, 3154 \mathrm{w}, 2926 \mathrm{w}, 1608 \mathrm{w}$, $1448 \mathrm{w}, 1280 \mathrm{~s}, 1246 \mathrm{~s}, 1166 \mathrm{~s}, 1032 \mathrm{~s}, 990 \mathrm{w}, 957 \mathrm{w}, 906 \mathrm{w}, 829 \mathrm{w}$, 805w, 750w, 639s, 574w, 517m, 408w. ${ }^{1} \mathrm{H}$ NMR $(399.78 \mathrm{MHz}$, $\left.\mathrm{CD}_{3} \mathrm{OD}\right): \delta=2.90\left(\mathrm{t},{ }^{3} J=5.6 \mathrm{~Hz}, 4 \mathrm{H}\right.$, en-CH$), 2.34\left(\mathrm{t},{ }^{3} J=5.6\right.$ $\mathrm{Hz}, 4 \mathrm{H}$, en-CH$), 1.87\left(\mathrm{t},{ }^{3} \mathrm{~J}=2.2 \mathrm{~Hz}, 4 \mathrm{H}, \mathrm{az}-\mathrm{CH}_{2}\right), 1.40\left(\mathrm{t},{ }^{3} \mathrm{~J}=\right.$ $\left.2.2 \mathrm{~Hz}, 4 \mathrm{H}, \mathrm{az}-\mathrm{CH}_{2}\right) .{ }^{13} \mathrm{C} \mathrm{NMR}\left(100.53 \mathrm{MHz}, \mathrm{CD}_{3} \mathrm{OD}\right): \delta=$ $121.83\left(\mathrm{q},{ }^{1} J_{\mathrm{C}-\mathrm{F}}=319 \mathrm{~Hz}, \mathrm{CF}_{3}\right), 62.56\left(\right.$ en- $\left.\mathrm{CH}_{2}\right), 42.87$ (en$\left.\mathrm{CH}_{2}\right), 33.98\left(\mathrm{az}-\mathrm{CH}_{2}\right), 28.30\left(\mathrm{az}-\mathrm{CH}_{2}\right) . \mathrm{MS}\left(\mathrm{FAB}^{+}\right): \mathrm{m} / \mathrm{z}(\%)=$ 427 (93) $\left[\mathrm{M}^{2+}+\right.$ OTf $], 277(80)\left[\mathrm{M}^{2+}\right], 191(48)\left[\mathrm{M}^{2+}-\mathbf{b}\right]$.

[Tris( $N$-(2-aminoethyl)aziridine- $\left.N, N^{\prime}\right) \operatorname{copper(II)]dichloride~(3b).~}$ The aziridine $\mathrm{C}_{2} \mathrm{H}_{5} \mathrm{NH}(8 \mathrm{~mL}, 149 \mathrm{mmol})$ was cooled down to $-10{ }^{\circ} \mathrm{C}$. Then anhydrous $\mathrm{CuCl}_{2}(1.55 \mathrm{~g}, 11.5 \mathrm{mmol})$ was added in small portions while stirring for $4 \mathrm{~h}$. After warming up to r.t. the blue mixture was stirred for $3 \mathrm{~d}$ and then the excess of $\mathrm{C}_{2} \mathrm{H}_{5} \mathrm{NH}$ was removed in vacuo. The residue was purified by stirring in $\mathrm{n}$-hexane overnight and dried in vacuo after separation from $\mathrm{n}$-hexane by pipette. Yield $4.35 \mathrm{~g}$ (11.0 mmol, 96\%), blue 
powder, m.p. $111{ }^{\circ} \mathrm{C}$ (dec.). Elemental analysis: Found: C, 36.65; $\mathrm{H}, 7.67 ; \mathrm{N}, 2$ 1.12. Calc. for $\mathrm{C}_{12} \mathrm{H}_{30} \mathrm{Cl}_{2} \mathrm{CuN}_{6}$ (392.86 g $\left.\mathrm{mol}^{-1}\right)$ : C, 36.69; H, 7.70; N, 21.39\%. UV/Vis: $\lambda_{\max }\left(\mathrm{CH}_{2} \mathrm{Cl}_{2}\right) /$ $\mathrm{nm} 721\left(\varepsilon / \mathrm{L} \mathrm{mol}^{-1} \mathrm{~cm}^{-1} 279\right)$. IR: $v_{\max } / \mathrm{cm}^{-1}(\mathrm{KBr}) 3192 \mathrm{~s}$, $3101 \mathrm{~s}, 2995 \mathrm{w}, 2966 \mathrm{w}, 2882 \mathrm{~m}, 1660 \mathrm{w}, 1602 \mathrm{~m}, 1448 \mathrm{~m}, 1359 \mathrm{w}$, $1323 \mathrm{w}, 1293 \mathrm{w}, 1259 \mathrm{~m}, 1222 \mathrm{w}, 1152 \mathrm{~m}, 1097 \mathrm{w}, 1063 \mathrm{~m}, 1008 \mathrm{~s}$, 936s, 902w, 861s, 834w, 816w, 787w, 755m, 708w, 553w, 450w. $\mathrm{MS}\left(\mathrm{FAB}^{+}\right): m / z(\%)=356(5)\left[\mathrm{M}^{2+} \times \mathrm{Cl}\right], 321$ (4) $\left[\mathrm{M}^{2+}\right]$, $270(100)\left[\mathrm{M}^{2+}+\mathrm{Cl}-\mathbf{b}\right], 240(31)\left[\mathrm{M}^{2+}-\mathbf{b}\right], 184(36)\left[\mathrm{M}^{2+}+\right.$ $\mathrm{Cl}-2 \mathbf{b}]$.

[Bis $\left\{N\right.$-(2-amino-2-methylpropyl)-2,2-dimethylaziridine- $\left.N, N^{\prime}\right\}$ chlorido-copper(II)]chloride (4c). The synthesis of $\mathbf{4 c}$ takes place analogously to that of $\mathbf{3 b}$ : Cooling of aziridine $\mathrm{CH}_{2} \mathrm{CMe}_{2} \mathrm{NH}$ (1 mL, $11.1 \mathrm{mmol})$, slowly adding $130 \mathrm{mg}(0.967 \mathrm{mmol})$ anhydrous $\mathrm{CuCl}_{2}$, reaction time 2 days and the same procedure of purification. Yield $388 \mathrm{mg}(0.930 \mathrm{mmol}, 96 \%)$, turquoise powder, m.p. $174{ }^{\circ} \mathrm{C}$ (dec.). Elemental analysis: Found: C, 45.93; $\mathrm{H}, 8.71 ; \mathrm{N}, 13.42$. Calc. for $\mathrm{C}_{16} \mathrm{H}_{36} \mathrm{Cl}_{2} \mathrm{CuN}_{4}(418.94 \mathrm{~g}$ $\left.\mathrm{mol}^{-1}\right)$ : C, 45.87; H, 8.66; N, 13.37\%. UV/Vis: $\lambda_{\max }\left(\mathrm{CH}_{2} \mathrm{Cl}_{2}\right) /$ $\mathrm{nm} 796\left(\varepsilon / \mathrm{L} \mathrm{mol}^{-1} \mathrm{~cm}^{-1} 380\right)$. IR: $v_{\max } / \mathrm{cm}^{-1}(\mathrm{KBr}) 3239 \mathrm{~s}$, $3136 \mathrm{~s}, 2992 \mathrm{~m}, 2968 \mathrm{~s}, 2878 \mathrm{~m}, 2734 \mathrm{w}, 1604 \mathrm{~m}, 1476 \mathrm{~m}, 1461 \mathrm{~m}$, $1393 \mathrm{~m}, 1382 \mathrm{~s}, 1373 \mathrm{~m}, 1348 \mathrm{~m}, 1338 \mathrm{~m}, 1282 \mathrm{w}, 1236 \mathrm{~m}, 1199 \mathrm{~m}$, $1151 \mathrm{~m}, 1111 \mathrm{~m}, 1067 \mathrm{w}, 1024 \mathrm{w}, 999 \mathrm{~m}, 948 \mathrm{~m}, 932 \mathrm{~m}, 924 \mathrm{~m}$, $867 \mathrm{~m}, 812 \mathrm{~s}, 773 \mathrm{~m}$. MS (FAB $\left.{ }^{+}\right): m / z(\%)=383(67)\left[\mathrm{M}^{+}\right], 348$ (30) $\left[\mathrm{M}^{+}-\mathrm{Cl}\right], 240(100)\left[\mathrm{M}^{+}-\mathbf{c}\right], 205(74)\left[\mathrm{M}^{2+}-\mathrm{Cl}-\mathbf{c}\right]$.

Following the suggestion of a reviewer that the dinuclear $\mathrm{Cu}$ (II) complex $\left[(\mu-\mathrm{Cl})\left(\mathrm{CH}_{2} \mathrm{CMe}_{2} \mathrm{NH}\right)_{2} \mathrm{ClCu}\right]_{2}$ (synthesized from $\mathrm{CuCl}_{2}$ in $\mathrm{CH}_{2} \mathrm{Cl}_{2}$ solution) ${ }^{67}$ could be a possible intermediate in the formation of $\mathbf{4 c}$, we repeated the synthesis of $\mathbf{4 c}$ as described above with this complex instead of $\mathrm{CuCl}_{2}$. Indeed we were able to detect $4 \mathbf{c}$ in the products of this reaction with $\mathrm{MS}\left(\mathrm{FAB}^{+}\right)$but further purification was not possible.

trans-Bis [(2H-phenylazirine)dichlorido]palladium(II)

(5d). $193 \mathrm{mg}(0.744 \mathrm{mmol})$ of $\mathrm{PdCl}_{2}$ in $20 \mathrm{~mL}$ of $\mathrm{CH}_{3} \mathrm{CN}$ was heated to reflux until it dissolved. Small amounts of insoluble components were filtered off and the solvent distilled off in vacuo. The orange yellow residue was dissolved in a mixture of $30 \mathrm{~mL}$ $\mathrm{CH}_{2} \mathrm{Cl}_{2}$ and $10 \mathrm{~mL} \mathrm{CH}_{3} \mathrm{CN}$. The resulting solution was combined with $174 \mathrm{mg}$ (1.488 mmol) 2H-3-phenylazirine d and stirred at r.t. for $0.5 \mathrm{~h}$. The solvent was removed in vacuo. Yield $200 \mathrm{mg}$ (0.419 mmol, 65\%), yellow-orange powder, m.p. $154{ }^{\circ} \mathrm{C}$ (dec.). Elemental analysis: Found: C, 46.22; H, 3.26; N, 6.70. Calc. for $\mathrm{C}_{16} \mathrm{H}_{14} \mathrm{Cl}_{2} \mathrm{~N}_{2} \mathrm{Pd}$ (411.62 $\mathrm{g} \mathrm{mol}^{-1}$ ): C, 46.69; H, 3.43; N, 6.81\%. IR: $v_{\max } / \mathrm{cm}^{-1}(\mathrm{KBr}) 3049 \mathrm{w}, 1777 \mathrm{vs}, 1597 \mathrm{w}, 1491 \mathrm{w}$, $1450 \mathrm{~m}, 1326 \mathrm{w}, 1308 \mathrm{w}, 1265 \mathrm{w}, 1185 \mathrm{w}, 1132 \mathrm{w}, 1020 \mathrm{~s}, 874 \mathrm{~m}$, $767 \mathrm{~s}, 699 \mathrm{~m}, 682 \mathrm{~s}, 543 \mathrm{~m} .{ }^{1} \mathrm{H}$ NMR $\left(399.78 \mathrm{MHz}, \mathrm{CDCl}_{3}\right): \delta=$ 8.37-8.34 (m, 4H, CH), 7.75-7.71 (m, 2H, CH), 7.65-7.61 (m, $4 \mathrm{H}, \mathrm{CH}), 2.23\left(\mathrm{~s}, 4 \mathrm{H}, \mathrm{CH}_{2}\right) .{ }^{13} \mathrm{C} \mathrm{NMR}\left(100.53 \mathrm{MHz}, \mathrm{CDCl}_{3}\right): \delta$ $=166.8\left(C_{\mathrm{q}}\right), 133.6(\mathrm{CH}), 132.4(\mathrm{CH}), 129.3(\mathrm{CH}), 121.6\left(C_{\mathrm{q}}\right)$, $20.9\left(\mathrm{CH}_{2}\right)$. MS $\left(\mathrm{FAB}^{+}\right): m / z(\%)=377(100)\left[\mathrm{M}^{+}-\mathrm{Cl}\right]$.

\section{Cell and cytotoxicity assay}

Cell cultures. Human skin melanoma WM-115 cells as well as human leukemia promyelocytic HL-60 and lymphoblastic NALM-6 cell lines were used. Leukemia cells were cultured in RPMI 1640 medium supplemented with $10 \%$ fetal bovine serum and antibiotics $\left(100 \mu \mathrm{g} \mathrm{mL} \mathrm{m}^{-1}\right.$ streptomycin and $100 \mathrm{U} \mathrm{mL}^{-1}$ penicillin). For melanoma WM-115 cells Dulbecco's minimal essential medium (DMEM) instead of RPMI 1640 was used. Cells were grown in $37{ }^{\circ} \mathrm{C}$ in a humidified atmosphere of $5 \%$ $\mathrm{CO}_{2}$ in air.

Cytotoxicity assay by MTT. Cytotoxicity of complexes 1a, $\mathbf{2 b}, \mathbf{3 b}, \mathbf{4 c}, \mathbf{5 d}$, cisplatin and carboplatin was determined by the MTT (3-(4,5-dimethylthiazol-2-yl)-2,5-diphenyltetrazolium bromide, Sigma, St. Louis, USA) assay as described. ${ }^{77}$ Briefly, after $46 \mathrm{~h}$ of incubation with drugs, the cells were treated with the MTT reagent, and incubation was continued for $2 \mathrm{~h}$. MTTformazan crystals were dissolved in 20\% SDS and 50\% DMF at $\mathrm{pH} 4.7$ and absorbance was read at $562 \mathrm{~nm}$ on an ELISA-plate reader (ELX 800, Bio-Tek, USA). The values of $\mathrm{IC}_{50}$ (the concentration of the tested compound required to reduce the cells survival fraction to $50 \%$ of the control) were calculated from concentration-survival curves and used as a measure of cellular sensitivity to a given treatment. Complexes, cisplatin and carboplatin were tested for their cytotoxicity in final concentrations from $10^{-7}$ to $10^{-3} \mathrm{M}$. As a control, cultured cells were grown in the absence of drugs. Data points represent means of 3-4 experiments, each performed at five repeats \pm S.D.

\section{Antibacterial activity}

Microorganisms. Gram-positive bacteria: Staphylococcus aureus ATCC 29213; S. epidermidis ATCC 12228; Enterococcus faecalis ATCC 29212; two Gram-negative bacteria: Escherichia coli NCTC 8196; Pseudomonas aeruginosa NCTC 6749, and yeast Candida albicans ATCC 10231, were used. The organisms were stored in TSB with $15 \%$ glycerol at $-70{ }^{\circ} \mathrm{C}$, and in each experiment cultures were established from the original stock.

Antibacterial activity testing. The susceptibility of microorganisms to complexes was determined by the standard CLSI (Clinical and Laboratory Standards Institute) broth microdilution method. Sterile stock solutions of each compound at the concentration of $60.0 \mathrm{mg} \mathrm{mL}^{-1}$ were prepared in DMSO. The agent concentration range used in the antimicrobial tests was 0.29-300.0 $\mu \mathrm{g} \mathrm{mL}^{-1}$ prepared for bacteria in Mueller-Hinton broth (Difco, USA), and for yeast in RPMI-1640 medium supplemented with L-glutamine and $\mathrm{NaHCO}_{3}$ (Biomed, Poland). Since stock solutions of chemicals were prepared in DMSO, this solubilizer alone was used as a control. To specify the minimal inhibitory concentrations (MIC), turbidometric $\left(\mathrm{OD}_{600}\right)$ studies were carried out using the multifunction counter Victor2 (Wallac, Finland). MIC was estimated as the lowest concentration of antimicrobial agent which gave drop in $\mathrm{OD}_{600}$ equal to the medium negative control (below 0.05 ), after $24 \mathrm{~h}$ at $37^{\circ} \mathrm{C}$ of co-incubation.

\section{Acknowledgements}

This work was supported by grants from the Medical University of Lodz No. 503/3-066-02/503-01 (to E. Budzisz) and No. 503/ 3-015-02/503-01 (to M. Rozalski and U. Krajewska). We thank Dr Karin Lux for the assistance in crystal structure solution. 


\section{Notes and references}

1 J. B. Sweeney, Chem. Soc. Rev., 2002, 31, 247-258.

2 I. D. Watson, L. Yu and A. K. Yudin, Acc. Chem. Res., 2006, 39, 194 206.

3 D. M. Noll, T. M. Mason and P. S. Miller, Chem. Rev., 2006, 106, 277301.

4 B. M. Trost and D. R. Fandrick, Org. Lett., 2005, 7, 823-826.

5 V. K. Yadav and V. Sriramurthy, J. Am. Chem. Soc., 2005, 127, 1636616367.

6 O. Ihata, Y. Kayaki and T. Ikariya, Macromolecules, 2005, 38, 64296434.

7 J. A. Katzenellenbogen, K. E. Carlson, D. F. Heiman, D. W. Robertson, L. L. Wei and B. S. Katzenellenbogen, J. Biol. Chem., 1983, 258, 34873495.

8 B. S. Iyengar, S. M. Sami, S. E. Tarnow, W. A. Remers, W. T. Bradner and J. E. Schurig, J. Med. Chem., 1983, 26, 1453-1457.

9 G. Sosnovsky and M. Konieczny, Synthesis, 1978, 583-585.

10 R. Kho, J. A. Hodges, M. R. Hansen and H. O. Villar, J. Med. Chem., 2005, 48, 6671-6678.

11 S. R. Rajski and R. M. Williams, Chem. Rev., 1998, 98, 2723-2796.

12 M. M. Paz, G. Suresh Kumar, M. Glover, M. J. Waring and M. Tomasz, J. Med. Chem., 2004, 47, 3308-3319.

13 K. Yokoi, K. Nagaoka and T. Nakashima, Chem. Pharm. Bull., 1986, 34, 4554-4561.

14 S. C. Schold Jr., J. E. Herndon, P. C. Burger, E. C. Halperin, N. A. Vick, J. G. Cairncross, D. R. Macdonald, E. J. Dropcho, R. Morawetz and D. D. Bigner, et al., J. Clin. Oncol., 1993, 11, 77-83.

15 Y.-C. Peng, H.-S. Kuo, H.-D. Tsai, Y.-P. Yang and Y.-L. Lin, Bioorg Med. Chem., 2006, 14, 263-272.

16 M. J. v. Maanen, C. J. M. Smeets and J. H. Beijnen, Cancer Treat. Rev, 2000, 26, 257-268.

17 Y. Palom, M. F. Belcourt, S. M. Musser, A. C. Sartorelli, S. Rockwell and M. Tomasz, Chem. Res. Toxicol., 2000, 13, 479-488.

18 I.-P. Lorenz and J. Kull, Angew. Chem., 1986, 98, 276-278.

19 J. Amarasekera, T. B. Rauchfuss and S. R. Wilson, J. Am. Chem. Soc., 1988, 110, 2332-2334.

20 R. F. Heck, J. Am. Chem. Soc., 1963, 85, 1460-1463.

21 D. Milstein and J. C. Calabrese, J. Am. Chem. Soc., 1982, 104, 37733774.

22 I.-P. Lorenz, J. Messelhäuser, W. Hiller and K. Haug, Angew. Chem., 1985, 97, 234-235.

23 I.-P. Lorenz, J. Messelhäuser, W. Hiller and M. Conrad, J. Organomet. Chem., 1986, 316, 121-138.

24 M. Herberhold and B. Schmidkonz, J. Organomet. Chem., 1988, 358, 301-320.

25 G. Beuter, S. Drobnik, I.-P. Lorenz and A. Lubik, Chem. Ber., 1992, 125, 2363-2366.

26 L. M. Atagi, D. E. Over, D. R. McAlister and J. M. Mayer, J. Am. Chem. Soc., 1991, 113, 870-874.

27 C. A. Root and J. W. Allison, Inorg. Chem., 1970, 9, 2791-2792.

28 D. V. Lefemine, M. Dann, F. Barbatschi, W. K. Hausmann, V. Zbinovsky, P. Monnikendam, J. Adam and N. Bohonos, J. Am. Chem. Soc., 1962, 84, 3184-3185.

29 J. C. Barnes, J. Iball and T. J. R. Weakley, Acta Crystallogr., Sect. B: Struct. Crystallogr. Cryst. Chem., 1975, 31, 1435-1437.

30 F. Porta, M. Pizzotti, G. La Monica, L. A. Finessi, S. Cenini, P. L. Bellon and F. Demartin, J. Chem. Soc., Dalton Trans., 1984, 2409-2414.

31 V. B. Ukraintsev, S. V. Yakovlev and Y. N. Kukushkin, Zh. Obshch Khim., 1987, 57, 1906-1907.

32 V. B. Ukraintsev, S. V. Yakovlev and Y. N. Kukushkin, Russ. J. Gen Chem., 1987, 57, 1704-1705.

33 D. C. Ware, B. G. Siim, K. G. Robinson, W. A. Denny, P. J. Brothers and G. R. Clark, Inorg. Chem., 1991, 30, 3750-3757.

34 D. C. Ware, D. S. Mackie, P. J. Brothers and W. A. Denny, Polyhedron, 1993, 12, 1371-1376.

35 W. R. Cantrell Jr, G. B. Richter-Addo and J. A. Gladysz, J. Organomet Chem., 1994, 472, 195-204.

36 D. C. Ware, D. S. Mackie, P. J. Brothers and W. A. Denny, Polyhedron, 1995, 14, 1641-1646.
37 S. v. Beckerath, I.-P. Lorenz, R. Fawzi and M. Steimann, Z. Naturforsch., B: Chem. Sci., 1996, 51b, 959-962.

38 R. B. Cheikh, R. Chaabouni, M. C. Bonnet and F. Dahan, Polyhedron, 1998, 17, 185-192.

39 R. Wilberger, H. Piotrowski, M. Warchhold and I.-P. Lorenz, Z. Anorg. Allg. Chem., 2003, 629, 2485-2492.

40 R. Wilberger, C. Krinninger, H. Piotrowski, P. Mayer, M. Ossberger and I.-P. Lorenz, Z. Anorg. Allg. Chem., 2004, 630, 1495-1500.

41 I.-P. Lorenz, C. Krinninger, R. Wilberger, R. Bobka, H. Piotrowski, M. Warchhold and H. Nöth, J. Organomet. Chem., 2005, 690, 19861993.

42 W. Beck, W. Danzer and R. Höfer, Angew. Chem., 1973, 85, 87-88.

43 W. Beck, W. Danzer, A. T. Liu and G. Huttner, Angew. Chem., 1976, 88, 511-512.

44 A. T. Liu, W. Beck, G. Huttner and H. Lorenz, J. Organomet. Chem., 1977, 129, 91-96.

45 W. Danzer, R. Hoefer, H. Menzel, B. Olgemoeller and W. Beck, Z. Naturforsch., B: Chem. Sci., 1984, 39b, 167-179.

46 M. M. Singh and R. J. Angelici, Inorg. Chem., 1984, 23, 2691-2698.

47 M. M. Singh and R. J. Angelici, Inorg. Chem., 1984, 23, 2699-2705.

48 R. Wilberger, Ph.D. Thesis, LMU, Munich, 2002.

49 R. Höfer, W. Beck and A. Engelmann, Chem. Ber., 1973, 106, 2590 2600.

50 H. P. Fritz and G. Hierl, Z. Naturforsch., B: Chem. Sci., 1971, 26b, 476.

51 M. Kojima, A. Sakurai, M. Murata, K. Nakajima, S. Kashino and Y. Yoshikawa, J. Coord. Chem., 1997, 42, 95-106.

52 C. Krinninger, Ph.D. Thesis, LMU, Munich, 2005.

53 R. Bobka, Ph.D. Thesis, LMU, Munich, 2007.

54 K. Dietliker, U. Schmid, G. Mukherjee-Mueller and H. Heimgartner, Chimia, 1978, 32, 164-166.

55 A. Hassner, C. A. Bunnell and K. Haltiwanger, J. Org. Chem., 1978, 43, $57-61$.

56 P. F. Dos Santos Filho and U. Schuchardt, J. Organomet. Chem., 1984, 263, 385-393.

57 H. Alper and J. E. Prickett, Inorg. Chem., 1977, 16, 67-71.

58 T. Izumi and H. Alper, Organometallics, 1982, 1, 322-325.

59 B. S. Iyengar, T. Takahashi, W. A. Remers and W. T. Bradner, J. Med. Chem., 1986, 29, 144-147.

60 M. Galanski and B. K. Keppler, Pharm. Unserer Zeit, 2006, 35, 118 123.

61 S. B. Wild, Coord. Chem. Rev., 1997, 166, 291-311.

62 J. N. Roedel, R. Bobka, M. P. Pfister, M. Rieger, B. Neumann and I.P. Lorenz, Z. Naturforsch., B: Chem. Sci., 2007, 62b, 1095-1101.

63 R. Bobka, J. N. Roedel, B. Neumann, T. Nigst and I.-P. Lorenz, Polyhedron, 2008, 27, 955-961.

64 T. B. Jackson and J. O. Edwards, J. Am. Chem. Soc., 1961, 83, 355-360.

65 T. B. Jackson and J. O. Edwards, Inorg. Chem., 1962, 1, 398-401.

66 J. N. Roedel, Ph.D. Thesis, LMU, Munich, 2008.

67 J. N. Roedel, R. Bobka, B. Neumann, B. Weber, P. Mayer and I.P. Lorenz, Z. Anorg. Allg. Chem., 2007, 633, 1171-1177.

68 P. H. Leung, A. C. Willis and S. B. Wild, Inorg. Chem., 1992, 31, 14061410 .

69 B.-H. Aw, T. S. A. Hor, S. Selvaratnam, K. F. Mok, A. J. P. White, D. J. Williams, N. H. Rees, W. McFarlane and P.-H. Leung, Inorg. Chem., 1997, 36, 2138-2146.

70 P.-H. Leung, K.-H. Ng, Y. Li, A. J. P. White and D. J. Williams, Chem. Commun., 1999, 2435-2436.

71 A. B. P. Lever, Inorganic Electronic Spectroscopy, Elsevier, Amsterdam, 2nd edn., 1984

72 G. A. McLachlan, G. D. Fallon, R. L. Martin and L. Spiccia, Inorg. Chem., 1995, 34, 254-261.

73 N. W. Mitzel, J. Riede and C. Kiener, Angew. Chem., 1997, 109, 2299 2300, (Angew. Chem., Int. Ed. Engl., 1997, 36, 2215-2216).

74 M. Duggan, N. Ray, B. Hathaway, G. Tomlinson, P. Brint and K. Pelin, J. Chem. Soc., Dalton Trans., 1980, 1342-1348.

75 S. Putzien, S. Wirth, J. Nicolas Roedel and I.-P. Lorenz, Polyhedron, 2011, 30, 1747-1751.

76 G. M. Sheldrick, Acta Crystallogr., Sect. A, 2008, 64, 112-122.

77 E. Budzisz, U. Krajewska, M. Rozalski, A. Szulawska, M. Czyz and B. Nawrot, Eur. J. Pharmacol., 2004, 502, 59-65. 